\title{
Efficiency of Lepidium sativum Seeds in Modulation the Alterations in Hematological Parameters Induced by Sodium Nitrite in Rats
}

\author{
Enas S. Abdel-Baky \\ Department of Biological and Geological Sciences, Faculty of Education, Ain Shams University, \\ Cairo, Egypt
}

\begin{abstract}
Background: Sodium nitrite is an inorganic compound with the chemical formula $\mathrm{NaNO}_{2}$. It is probably best known as a food additive to prevent botulism.

Aim of the work: The current study was designed to investigate the possible protective effect of aqueous extract of Lipidium sativum seeds on hematotoxicity induced by sodium nitrite $\left(\mathrm{NaNO}_{2}\right)$ in male albino rats.

Materials and Methods: The experimental animals were divided into four groups. The first group without any treatment and served as control. The second group was given an intraperitoneal injection (IP) of a single dose of sodium nitrite $(50 \mathrm{mg} / \mathrm{kg}$ body weight $) 24 \mathrm{~h}$ prior to decapitation. The third group was received orally $300 \mathrm{mg} / \mathrm{kg}$ body weight of Lipidium sativum seeds extract for four weeks. The fourth group were treated orally with Lipidium sativum seeds extract ( $300 \mathrm{mg} / \mathrm{kg}$ body weight) for four weeks, prior to IP injection with a single dose of sodium nitrite $(50 \mathrm{mg} / \mathrm{kg}$ body weight). Finally, blood samples were collected for hematological parameters estimation including red blood cell count (RBCs), hemoglobin (Hb), packed cell volume (PCV), mean corpuscular volume (MCV), mean corpuscular hemoglobin $(\mathrm{MCH})$, mean corpuscular hemoglobin concentration (MCHC), platelet count (PLTs) and total and differential white blood cells (WBCs).
\end{abstract}

Results: The obtained data revealed that $\mathrm{NaNO}_{2}$ induced a significant decrease in the percentages of RBCs count, Hb content, PCV, MCH, MCHC, platelets, WBCs, neutrophils, monocytes, eosinophils and basophils count. On the other hand, a noticeable increase in the percentage of lymphocytes was recorded in $\mathrm{NaNO}_{2}$ treated rats. Whereas, the treatment with Lipidium sativum seeds extract alone to rats did not cause a significant alterations in the hematological indices comparing to control group. There was a significant increase in total WBCs and neutrophils counts and a significant decrease in lymphocyts, monocyts, eosinophils and basophils counts. The treatment with Lipidium sativum seeds extract before injection with sodium nitrite were significantly ameliorated the changes induced in hematological parameters which caused by sodium nitrite comparing with the control group. Whereas, there were a significant increase in total WBCs count, neutrophils and eosinophils and a significant decrease in lymphocytes, monocytes and basophils.

Conclusion: It could be concluded that the treatment with Lipidium sativum seeds extract significantly improved the changes in hematological parameters that caused by sodium nitrite and induced a significant increase of WBCs count may stimulate the animal's immune system activation.

Key words: Hematological parameters, Lepidium sativum seeds, Sodium nitrite.

\section{INTRODUCTION}

Food additives are substances intentionally added to food and used for various purposes, including preservation, coloring and enhance food ${ }^{(1)}$.They are products of oxidation of nitrogen by microorganisms in plants, soils and water. Nitrites are used as food additives mainly for production of specific flavor and for preservation of meat products. Several organic nitrites and nitrates have been used clinically but the only inorganic nitrite of therapeutic using is sodium nitrite ${ }^{(2)}$. The nitrites used in the form of salts or free acids and it is one of the principal preservatives. Previous researchers reported that nitrites are environmental pollutants present in food and water and it is responsible for most of the toxic effects observed with excess nitrate ingestion (3). Sodium nitrite is a white to slightly yellowish inorganic salt, with the chemical formula NaNO2. It may interact in the stomach with amines of the foods, producing nitrosamines or free radicals (4). These products may induce lipid peroxidation that may increase the harmful hazards to the 
different organs of the body ${ }^{(5)}$, including liver and kidney ${ }^{(6)}$. Also, Sodium nitrite in blood is highly reactive with hemoglobin, so affecting hematopoiesis process. It reduce hemoglobin's ability to transport oxygen a major concern in considering the toxicology of sodium nitrite is the induction of methemoglobinemia, a condition in which there is a reduction in hemoglobin's ability to transport oxygen ${ }^{(7)}$.

The garden cress (Lepidium sativum) belongs to Brassicaceae family; it is present in Egypt and west Asia. The seeds are used enormously as salad and spice ${ }^{(8)}$. It has a wide therapeutic application, so it has been used widely around the world, the previous studies have reported the protective action of the plant against carcinogenic compounds and growth prevention of Pseudomonas aeruginosa, a bacteria strain has a strong antibiotic resistance ${ }^{(9)}$.The leaves and seedpods have been reported to have various biological activities including antioxidant, anti-inflammatory, hepatoprotective effect against oxidative damage, and therefore, it is used as dietary supplements ${ }^{(10)}$.

The aim of the current work was to investigate the possible protective effect of aqueous extract of Lipidium sativum seeds on hematotoxicity induced by sodium nitrite $\left(\mathrm{NaNO}_{2}\right)$ in male albino rats.

\section{Materials and methods \\ Chemicals}

Sodium nitrite $\left(\mathrm{NaNO}_{2}\right)$ was purchased from sigma Aldrich, St Louis, Mo. It was prepared as a freshly solution by dissolving $5 \mathrm{~g}$ in 100 $\mathrm{ml}$ saline solution, and was administered intraperitoneally (IP) at $50 \mathrm{mg} / \mathrm{kg}$ body weight (1 ml dosing volume) according to Gluhcheva et al. ${ }^{(7)}$.

\section{Preparation of plant extract (Lepidium sativum seeds extract)}

Lepidium sativum seeds (known as garden cress) (LS) were obtained from Agricultural Research Center, Egypt. Briefly, the grinded seeds were washed, dried and crushed to powder using electric blender. The freshly prepared suspension of garden cress seeds powder were administered to each rat orally by stomach tube at a dose $300 \mathrm{mg} / \mathrm{kg}$ body weight once daily for four weeks.

\section{Experimental animals}

Twenty-four male albino rats (Rattus norvegicus) weighing 125-150 g were used throughout the experiments. The animals were housed in metal cages in a conditioned room and were provided with a standard laboratory diet and water ad libitum. They were purchased from animal house colony of the national research center.

\section{Experimental design}

The rats were divided randomly into four groups $(n=6)$. The first group rats received no treatment and served as control; the second group rats received a single dose of sodium nitrite intraperitoneally $(50 \mathrm{mg} / \mathrm{kg}$ body weight) $24 \mathrm{~h}$ before decapitation; the third group rats received orally garden cress extract (300 mg/kg body weight) for four weeks; The fourth group rats received garden cress extract orally ( $300 \mathrm{mg} / \mathrm{kg}$ body weight) for four weeks and then received a single dose of sodium nitrite intraperitoneally $(50 \mathrm{mg} / \mathrm{kg}$ body weight) $24 \mathrm{~h}$ before decapitation.

The rats were starved for $12 \mathrm{~h}$ overnight prior the collection of blood samples. Rats were anaesthetized with ethyl ether and the blood was collected in sterilized vials by cervical dislocation.

\section{Hematological studies:}

A part of blood samples was collected in EDTA vials. Red and white blood cell counts, hemoglobin concentration, mean corpuscular hemoglobin $(\mathrm{MCH})$, mean corpuscular volume (MCV), mean corpuscular hemoglobin concentration (MCHC) and platelets count were performed according to Dacie and Lewis methods.

\section{Differential Leucocytes Count}

Freshly collected blood samples of $20 \mu \mathrm{l}$ were spread on clean slides as a thin film. Each smear was left to air dried and fixed with methanol for 2-3 min and then labeled. After that, blood smears were stained with $10 \%$ Giemsa's stain (Aldrich), examined under light microscopy and different types of blood leucocytes were counted according to Schalm.

\section{Statistical analysis}

Data were expressed as means \pm S.E. Statistical analysis was performed using one-way analysis of variance (ANOVA) followed by Duncan's multiple range tests. 


\section{Results}

The data represented in tables $(1 \& 2)$ display the effects of treatment on hematological indices. There were a significant reduction in RBCs count, $\mathrm{Hb}, \mathrm{PCV}, \mathrm{MCV}, \mathrm{MCH}, \mathrm{MCHC}$ and PLT in the sodium nitrite-treated group comparing to the control group (Table 1).On the other hand, the garden cress treated group shows a normal values in these hematological parameters. Co-administration of sodium nitrite with the garden cress extract were significantly prevented to some extent the changes recorded in sodium nitrite group in these parameters as compared with control group.

Results presented in table (2) show the alterations of the WBCs count and the differential white blood cell counts. In sodium nitrite treated group, there were a significant decrease in WBCs count and differential white blood cells count, including neutrophils, monocytes, eosinophils and basophils. Whereas, there was a significant increase in lymphocytes count comparing with the control group. The garden cress treated group revealed a significant increase in the count of total WBCs and neutrophils. But, the count of lymphocytes, monocytes, eosinophils and basophils were significantly decreased comparing with the control values. On the other hand, in the co-administration of sodium nitrite and the garden cress extract treated group, the total white blood cells count and neutrophils were significantly increased. Whereas, there were a significant decrease in the lymphocytes and the monocytes count compared to the control group.

Table (1): Effect of orally administrated with garden cress extract on the hematological parameters in rats intoxicated with sodium nitrite.

\begin{tabular}{|c|c|c|c|c|c|c|c|c|}
\hline Groups & Control & $\mathrm{Na} \mathrm{NO}_{2}$ & $\% \mathrm{D}$ & $\begin{array}{l}\text { Garden } \\
\text { cress }\end{array}$ & $\% \mathrm{D}$ & $\begin{array}{c}\mathrm{Na} \mathrm{NO}_{2} \\
+ \\
\text { Garden } \\
\text { Cress }\end{array}$ & $\% \mathrm{D}$ & $\begin{array}{c}\text { p- } \\
\text { value }\end{array}$ \\
\hline$\underset{\left(\mathbf{x 1 0}^{6} / \mathrm{mm}^{3}\right)}{\text { R.B.Cs }}$ & $6.72 \pm 0.32^{\mathrm{a}}$ & $5.43 \pm 0.211^{\mathrm{b}}$ & -19.2 & $6.71 \pm 0.1^{\mathrm{a}}$ & -0.15 & $6.57 \pm 0.2^{\mathrm{a}}$ & -2.23 & $*$ \\
\hline$\underset{(\mathrm{g} / \mathrm{dl})}{\mathbf{H b}}$ & $13.3 \pm 0.204^{\mathrm{a}}$ & $9.8 \pm 0.45^{\mathrm{b}}$ & -26.32 & $13.03 \pm 0.15^{\mathrm{a}}$ & -2.03 & $12.5 \pm 0.23^{\mathrm{a}}$ & -6.02 & $*$ \\
\hline PCV\% & $38.8 \pm 0.6^{a}$ & $31.24 \pm 1.65^{\mathrm{b}}$ & -19.5 & $39.82 \pm 0.5^{\mathrm{a}}$ & 2.63 & $38.5 \pm 0.52^{\mathrm{a}}$ & -0.8 & $*$ \\
\hline $\begin{array}{c}\text { MCV } \\
(\text { FL) }\end{array}$ & $57.23 \pm 0.4^{\mathrm{ab}}$ & $56.94 \pm 1.02^{\mathrm{ab}}$ & -0.51 & $59.6 \pm 1.34^{\mathrm{ab}}$ & 4.14 & $56.65 \pm 0.51^{\mathrm{ab}}$ & -1.013 & $*$ \\
\hline $\begin{array}{c}\text { MCH } \\
(\mathbf{p g})\end{array}$ & $18.53 \pm 0.22^{\mathrm{a}}$ & $17.92 \pm 0.2^{\mathrm{b}}$ & -3.3 & $19.4 \pm 0.22^{\mathrm{c}}$ & 4.7 & $17.98 \pm 0.12^{b}$ & -3 & $*$ \\
\hline$\underset{(\%)}{\operatorname{MCHC}}$ & $32.9 \pm 0.21^{\mathrm{a}}$ & $31.4 \pm 0.24^{b}$ & -4.6 & $32.7 \pm 0.4^{\mathrm{a}}$ & -0.61 & $31.32 \pm 0.33^{b}$ & -4.8 & $*$ \\
\hline$\underset{\left(\times 10^{3} / \mathbf{m m}^{3}\right)}{\text { PLT }}$ & $597 \pm 11.31^{\mathrm{a}}$ & $372.33 \pm 24.8^{\mathrm{b}}$ & -37.63 & $571 \pm 16.1^{\mathrm{a}}$ & -4.4 & $507 \pm 19.03^{c}$ & -15.1 & $*$ \\
\hline
\end{tabular}

Values represent mean \pm S.E. of 6 rats

$\%$ D: Percentage difference [ (Treated value - Control Value) / Control Value] x 100

Different letters indicate significantly different means $\mathrm{p}$-value $<0.05$

Same letters indicate non significant changes. 
Table (2): Effect of orally administrated with garden cress extract on total leucocytes count and differential leukocytes count in rats intoxicated with sodium nitrite.

\begin{tabular}{|c|c|c|c|c|c|c|c|c|}
\hline Groups & Control & $\mathrm{Na} \mathrm{NO}_{2}$ & $\% \mathrm{D}$ & Garden cress & $\% \mathrm{D}$ & $\begin{array}{c}\mathrm{Na} \mathrm{NO}_{2} \\
+ \\
\text { Garden } \\
\text { cress }\end{array}$ & $\% \mathrm{D}$ & p-value \\
\hline $\begin{array}{c}\text { W.B.Cs } \\
\left(\times 10^{9} / \mathrm{L}\right)\end{array}$ & $7.9 \pm 0.13^{\mathrm{a}}$ & $6.02 \pm 0.23^{\mathrm{b}}$ & -23.8 & $10.5 \pm 0.25^{\mathrm{c}}$ & 32.9 & $9.52 \pm 0.3^{\mathrm{d}}$ & 20.5 & $*$ \\
\hline $\begin{array}{c}\text { Neutrophils } \\
(\%)\end{array}$ & $24.6 \pm 1.12^{\mathrm{a}}$ & $1.5 \pm 0.2^{\mathrm{b}}$ & -93.9 & $51.33 \pm 1.3^{\mathrm{c}}$ & 108.66 & $52.5 \pm 1.34^{\mathrm{c}}$ & 113.41 & $*$ \\
\hline $\begin{array}{c}\text { Lymphocytes } \\
(\%)\end{array}$ & $63.85 \pm 1.01^{\mathrm{a}}$ & $93.23 \pm 0.7^{b}$ & 46.01 & $40.33 \pm 1.2^{c}$ & -36.84 & $37.7 \pm 1.7^{\mathrm{c}}$ & -40.96 & $*$ \\
\hline $\begin{array}{c}\text { Monocytes } \\
(\%)\end{array}$ & $6.9 \pm 0.2^{\mathrm{a}}$ & $4.3 \pm 0.6^{\mathrm{b}}$ & -37.7 & $5.1 \pm 0.3^{b}$ & -26.1 & $5.33 \pm 0.3^{\mathrm{b}}$ & -22.8 & $*$ \\
\hline $\begin{array}{c}\text { Eosinophil } \\
(\%)\end{array}$ & $4.24 \pm 0.31^{\mathrm{a}}$ & $0.72 \pm 0.2^{\mathrm{b}}$ & -83.02 & $3.2 \pm 0.1^{\mathrm{c}}$ & -24.53 & $4.3 \pm 0.31^{\mathrm{a}}$ & 1.42 & $*$ \\
\hline $\begin{array}{c}\text { Basophils } \\
(\%)\end{array}$ & $0.5 \pm 0.015^{\mathrm{a}}$ & $0.23 \pm 0.06^{\mathrm{abc}}$ & -54 & $0.1 \pm 0.04^{b c}$ & -80 & $0.3 \pm 0.06^{\mathrm{abc}}$ & -40 & $*$ \\
\hline
\end{tabular}

Values represent mean \pm S.E. of 6 rats

$\%$ D: Percentage difference [(Treated value - Control Value) / Control Value] x 100

Different letters indicate significantly different means $\mathrm{p}$-value $<0.05$

Same letters indicate non significant changes.

\section{Discussion}

Hematological parameters and the examination of the extent of their deterioration is a useful tool for determination of many diseases. This is because the alteration in blood components is related to the physiological conditions of the animals. Hematological investigations are serious because blood is the main transport system of the body and the hematological estimation usually gives important information on the body's response to all forms of injury, such as toxic injury ${ }^{(11)}$.

The purpose of this research work was to determine the protective effects of oral administration of garden cress aqueous extract to rats treated with the sodium nitrite on hematological parameters. The varied levels of significance noticed in the hematological parameters evaluated in this study (postadministration) between the control and the test groups shows that there is an obvious connection between the intake of sodium nitrite, the aqueous extract of garden cress and co-administration between them and the degree of hematological effects that observed. The present work showed that the treatment of rats with sodium nitrite caused a highly significant decrease in the red blood cells, white blood cells and platelets counts. Also, there are a highly significant decrease in hemoglobin concentration, packed cell volume, means corpuscular hemoglobin, mean corpuscular hemoglobin concentration, mean corpuscular volume values as compared to the control group. Otherwise, there is a highly significant elevation in the count of lymphocytes comparing with control group. The outcome of the present investigation shows that, sodium nitrite causes a significant impact on the different hematological parameters compared to the control. These findings agreed with other researchers ${ }^{(12)}$, that reported a significant decrease in RBCs count, $\mathrm{Hb}$ concentration, $\mathrm{MCHC}$ value in the group treated with sodium nitrite. Also, a significant decrease in $\mathrm{Hb}$ concentration in the rats that received a high dose of sodium nitrite were reported by Ibrahim et al. ${ }^{(13)}$. Furthermore, Azabet al ${ }^{(14)}$, recorded that the administration of sodium nitrite showed a significant decrease in the count of platelets and WBCs in the sodium nitrite treated Guinea pigs. Decreased $\mathrm{RBC}$ s count is seen in some anemias. $\mathrm{Hb}$ and 
MCHC values are also very important for diagnosis of such anemias. The decreasing of $\mathrm{RBCs}$ count and $\mathrm{Hb}$ concentration may be due to the toxic effect of sodium nitrite on bone marrow, spleen and liver ${ }^{(12)}$ or may be due to the direct interaction of sodium nitrite on $\mathrm{Hb}$, where it oxidizes the ferrous ion of the oxyhemoglobin (oxy $\mathrm{Hb}$ ) molecules to the ferric state forming met $\mathrm{Hb}$, leading to cell destruction ${ }^{(13)}$. The membrane and cytoplasmic structures are influenced by an oxidant attack (15). The reduction in WBCs count lower the defense mechanism (immune system), that play an important role in attacking and interacting with foreign antigens and initiating a primary immune response. The decrease in WBCs count after treatment with sodium nitrite may be due to the failure of the hematopoietic tissues to produce new WBCs (16). From the result of the differential white cells count that carried out in this study, the observed increase in lymphocytes count in sodium nitrite treated group might be attributed to the interaction between sodium nitrite and gastrointestinal macrophages, which act as a toxic agent. Macrophages cause the activation of the helper $\mathrm{T}$ cells and the B lymphocytes, by serving as antigen presenting cell and the antigenic products (polypeptides) ${ }^{(17)}$.They also secrete substances called interleukin-1/-cytokines, that stimulate the activation of lymphocytes and increase their count ${ }^{(17)}$. The main function of lymphocyte is the response to antigen (foreign bodies) by the development of cellular immunity and forming antibodies circulating in the blood ${ }^{(18)}$.

Sodium nitrite might be has a toxic effect on the neutrophils and monocytes cells in the blood or it has a serious effect on the bone marrow, causing the reduction of these blood cells production. Neutrophils with monocytes considered as the first line defense against toxic substances, foreign substances and microorganisms ${ }^{(19)}$. This might be indicator to the disturbance of immune status in the treated animals responding to the toxic effect of sodium nitrite. Also, there were a significant decrease in the eosinophils count that attack multicellular parasites and some infections in vertebrates. In addition to, basophiles were affected in the treated animals comparing with the control group. Some previous studies suggested that basophiles could be regulating the behavior of $\mathrm{T}$ cells and the secondary response of immunity ${ }^{(20)}$.
Herbal medicine can promote health and alleviate illness, due to the fact that plants contain natural substances (21). They have shown a strong power in modern phytomedicine against various ailments and the complex diseases and make a various assistance to the health care. The present study showed that the intake of garden cress aqueous extract alone to male albino rats did not reveal a significant change in the hematological parameters comparing to control group. These results are similar to that of Datta et al. ${ }^{(22)}$, who reported that garden cress treatment did not show a significant change in the hematological indices.Since, the hematological indices that studied in the present investigation revealed the normal range values; it may be assumed that garden cress did not have serious effects on the animals during the experiment which lasted through four weeks. In other words, there was a significant increase in WBCs count, that means the garden cress contains substances have antibiotic effects ${ }^{(9)}$, that should stimulate the proliferation of circulating white blood cells to protect the body from teratogens. Eosinophils cells demonstrated a significant decrease in the garden cress treated group comparing with the control group. This decrease in the eosinophils count shows the antioxidant activities of garden cress aqueous extract as the free radical agent stimulate production of more eosinophils.

Co-administration of sodium nitrite and garden cress aqueous extract were improved the alterations recorded in hematological parameters significantly that caused by treatment of rats with sodium nitrite only comparing with the control group. It may be due to the garden cress extract stimulate blood formation due to the presence of essential nutrients and better feed intake ${ }^{(23)}$ and due to the availability of important minerals especially $\mathrm{Fe}, \mathrm{Cu}, \mathrm{Mn}$ and $\mathrm{Ca}$ in the garden cress powder ${ }^{(24)}$. Garden cress also contains flavonoid and polyphenolic compounds that responsible for its strong antioxidant capacity that might prevent lipid peroxidation in the membranes of erythrocytes, leading to increasing membrane resistance to spontaneous hemolysis, decreasing membrane micro-viscosity, maintenance of their integrity and functional activity ${ }^{(25)}$. The significant increase in WBCs count refers to the activation of the animal's immune system. So, 
it has been suggested that garden cress intake increased WBCs precursors proliferation from pluripotent stem cell in rats.

\section{Conclusion}

From the previous results, it could be stated that the intake of sodium nitrite has been demonstrated to alter the hematological parameters in male albino rats. The supplementation with garden cress aqueous extract have demonstrated a strong potential benefits by stimulated of blood parameters that inducing good health and remaining blood factors that necessary for body defense.

\section{References}

1-AL-Shinnawy MS (2009): Physiological effect of a food additive on some haematological and biochemical parameters of male albino rats. Egypt. Acad. J. biolog. Sci., 2 (1): 143-151.

2-Heihashy and Abd El-Moneim (1999): Blood lipid profile and serum free thyroidal hormone concentrations in growing rats fed diets enriched with sodium nitrate for short and long terms. J. Egypt. Ger. Soc. Zool.,30 (A): 93-103.

3-Feelisch M and Stamler JS (1996): Donors of nitrogen oxides In: Methods in Nitric Oxide Research (Feelisch M \& Stamler JS \&Chichester, eds), pp. 71-115, Wiley, UK. 4-Aboulgasem GJA, Azab $S$ and Almaky MM (2015): Sodium nitrite induced biochemical alterations in the blood serum and its amelioration by aqueous extract of Libyan Propolis in Guinea Pigs. International Journal of Sciences and Research (IJSR), 4(8):10401048.

5-Abdeen AM, EL-Shayeb AF, Hassan HA and El-Agamy SA (2015): The protective role of garlic oil against the histo-pathological and histochemical changes induced by sodium nitrite toxicity in kidneys of albino rats. J. Jazan. Univ. Appl. Sci. Branch, (4):57-67.

6-Choi SY, Chung MJ and Sung NJ (2002): Volatile N-nitrosamine inhibition after intake of Korean green tea and Maesil (Prunusmume SIEB. et ZACC.) extracts with an amine-rich diet in subjects ingesting nitrate. Food Chem. Toxicol., 40:949-957.

7-Gluhchevaa Y, IvanovbI, Petrovaa E, Pavlovaa E and Vladova I (2012): Sodium nitrite-induced hematological and hemorheological changes in rats. Series on Biomechanics, 27(3-4):53-58.
8-Gokavi SS, Malleshi NG and Guo M (2004): Chemical composition of garden cress (Lepidium sativum) seeds and its fractions and use of bran as a functional ingredient. Plant Food. Hum. Nutr., 59:105-111.

9-Kassie F, Laky B, Gminski R, MerschSundermann V, Scharf G, Lhoste E and Kansmuller S (2003): Effects of garden and water cress juices and their constituents, benzyl and phenethyl isothiocyanates, towards benzo (a) pyrene-induced DNA damage: a model study with the single cell gel electrophoresis/Hep G2 assay. Chemical Biology Interactions, 3:285-296.

10-Sakran M, Selim Y and Zidan N (2014): A new isoflavonoid from seeds of Lepidium sativum L. and its protective effect on hepatotoxicity induced by paracetamol in male rats. Molecules, 19(10):15440-51.

11-Ihedioha JT, Okafor $C$ and IhediolaTE (2004): The haematological profile of the Sprague Dawley out-bred albino rat in Nsukka. Anim. Res. Intern., 1:125-132.

12-Abu Aita NA and Mohammed FF (2014): Effect of marjoram oil on the clinicopathological, cytogenetic and histopathological alterations induced by sodium nitrite toxicity in rats. Glob. Veter.,12(5):606-616.

13-Ibrahim IA, Hassan AGA, Shalaby AA, Dessouki AA and Habib DS (2009): Biochemical studies on the effect of sodium nitrite and butylated hydroxytoluene in rats. SCVMJ.,14 (2):265-278.

14-Azab AE, Lashkham NM and Albasha MO (2015):Haemato-Protective and Hypolipidemic Effects of Aqueous Extract of Libyan Propolis Against Sodium Nitrite Induced Haematotoxicity and Hyperlipidemia in Guinea Pigs. American Journal of Bioscience and Bioengineering, 3(4):22-32.

15-Baskurt OK and Yavuzer S (1994): Some haematological effects of oxidants. In: Nriagu JO, Simmons MS (eds). Environmental Oxidants.John Wiley and Sons Inc, New York /Chichester/Brisbane/Toronto/Singapore.

16-Tan YS, Nambiar R and Yo SL (1992): Prevalence of protein calorie malnutrition in general surgical estimating total serum lipid. Clin. Chem., 18: 199-202.

17-Sembulingham $K$ (2005): Essentials of medical Physiology $2^{\text {nd }}$ ed. pp.46-56.

18-Frandson RD (2003): Anatomy and Physiology of Farms Animals. Chap. 31.Pp. 462. 
19-Hall JE (2011): Guyton and Hall Textbook of Medical Physiology. $12^{\text {th }}$ Edition, Philadelphia, pp. 423-431.

20-Nakanishi K (2010): Basophils are potent antigen-presenting cells that selectively induce Th2 cells. Eur. J. Immunol., 40: 1836-1842.

21-Moon K, Khadabadi SS, Deokate UA and Deore SL (2010): Caesalpinia bonducella F-An Overview. Report and Opinian, 2(3): 8390.

22-Datta PK, Diwakar BT, Viswanatha S, Murthy KN and Naidu KA(2011): Safety evaluation studies on Garden cress (Lepidium sativum L.) seeds in Wistar rats. International Journal of Applied Research in Natural Products, 4 (1): 37-43.
23-Shawle K, Urge M and Animut G (2016): Effect of different levels of Lepidium sativum $\mathrm{L}$. on growth performance, carcass characteristics, hematology and serum biochemical parameters of broilers. Springerplus, 5(1):1441.

24-Zia-Ul-Haq M, Ahmad S, Calani L, Mazzeo T, Rio DD, Pellegrini $N$ and De FV (2012): Compositional study and antioxidant potential of Ipomoea hederacea Jacq.and Lepidium sativum L. seeds. Molecules, 17: 10306-10321.

25-Halaby MS, Farag MH and Mahmoud SAA (2015): Protective and Curative Effect of Garden Cress Seeds on Acute Renal Failure in Male Albino Rats. Middle East Journal of Applied Sciences, 5(2): 573-586. 